Life Science 10 (1) (2021)

Life Science

http://journal.unnes.ac.id/sju/index.php/LifeSci

\title{
Perbedaan Kadar IgA dan IL6 Pada Penumpang "Biosmart and Safety Bus" pada Memakai Masker Herbal dan Masker Medis
}

\author{
Herera Rahajeng $^{\bowtie 1)}$, Awal Prasetyo ${ }^{2)}$, Neni Susilaningsih ${ }^{3)}$, Udadi Sadhana ${ }^{4)}$, Nani Maharani ${ }^{5)}$, \\ Hairul Asri')
}

1),3),4)56) Jurusan Ilmu Biomedik, Fakultas Kedokteran, Universitas Diponegoro, Semarang, Indonesia

\begin{tabular}{|c|c|}
\hline Info Artikel & Abstract \\
\hline $\begin{array}{l}\text { Diterima: 1 Maret } 2021 \\
\text { Disetujui: } 30 \text { Maret } 2021 \\
\text { Dipublikasikan: } 15 \text { April } \\
2021\end{array}$ & \multirow{3}{*}{$\begin{array}{l}\text { Viral infections that attack the respiratory tract are currently a major problem globally. The spread of viral } \\
\text { infection can be one of the risks by passengers of the bus. The government's efforts being developed are the } \\
\text { application of biosmart and safety buses designed to prevent the virus with stake holders. One of the health } \\
\text { protocols is the use of masks. The purpose of this study was to see the differences in IgA and IL6 levels before } \\
\text { and after the use of medical masks and herbal masks. Nasal wash samples were taken and analyzed by ELISA. } \\
\text { The results obtained were the level of IgA for the control group before wearing medical masks was } 23.46834 \\
\mathrm{pg} / \mathrm{ml} \text { and after wearing } 29.74473 \mathrm{pg} / \mathrm{ml} \text {. While the IL6 levels before were } 1.10544 \mathrm{ng} / \mathrm{ml} \text { and after }-2.04119 \\
\mathrm{ng} / \mathrm{ml} \text {. The results of the IgA in the experimental group before using the herbal mask } 24.00840 \mathrm{pg} / \mathrm{ml} \text { and } \\
\text { after using was } 29.74473 \mathrm{pg} / \mathrm{ml} \text {. Meanwhile, the level of IL6 before was } 0.91682 \mathrm{ng} / \mathrm{ml} \text { and after } 0.500157 \\
\mathrm{ng} / \mathrm{ml} \text {. Based on the results, there was an increase in IgA levels after the use of medical masks and herbal masks } \\
\text { while IL6 levels decreased after the use of medical and herbal masks.. }\end{array}$} \\
\hline $\begin{array}{l}\text { Keywords: } \\
\text { Herbal mask; IgA; IL6 } \\
\text { Masker herbal;IgA;IL6 }\end{array}$ & \\
\hline & \\
\hline
\end{tabular}

\begin{abstract}
Abstrak
Infeksi virus yang menyerang saluran pernapasan saat ini menjadi masalah utama secara global. Penyebaran agen infeksi virus dapat menjadi salah satu risiko yang dihadapi penumpang moda transportasi Bus. Upaya Pemerintah seperti yang saat ini dikembangkan adalah pengaplikasian biosmart and safety bus yang dirancang guna menghambat persebaran virus dengan stake holder yang tepat. Salah satu penerapan protokol kesehatan adalah penggunaan masker. Tujuan dari penelitian ini adalah melihat perbedaan kadar IgA dan IL6 sebelum dan sesudah pemakaian masker medis dan masker herbal pada penumpang biosmart and safety bus. Pengambilan sampel nasal wash dilakukan dan dianalisis dengan ELISA. Penelitian ini merupakan quasi experimental dengan prepost test randomized control design. Hasil yang didapat adalah kadar IgA untuk kelompok kontrol sebelum pemakaian masker medis $23,46834 \mathrm{pg} / \mathrm{ml}$ dan setelah memakai masker medis $29,74473 \mathrm{pg} / \mathrm{ml}$. Sementara kadar IL6 sebelum adalah 1,10544 ng/ml dan setelah -2,04119 ng/ml. Hasil IgA kelompok eksperimen sebelum pemakaian masker herbal 24,00840 pg/ml dan setelah memakai masker herbal 29,74473 pg/ml. Sementara kadar IL6 sebelum adalah 0,91682 ng/ml dan setelah $0,500157 \mathrm{ng} / \mathrm{ml}$. Berdasarkan hasil penelitian terdapat peningkatan kadar IgA setelah pemakaian masker medis dan masker herbal sementara kadar IL6 mengalami penurunan setelah pemakaian masker medis dan masker herbal.
\end{abstract}

(C) 2021 Universitas Negeri Semarang

$\square$ Alamat korespondensi:

p-ISSN 2252-6277

Gedung Dekanat FK Undip Lt.2 J1 Dr Soetomo RSUP Kariadi, Semarang

E-mail: hereragarfield@gmail.com

e-ISSN 2528-5009 


\section{PENDAHULUAN}

Infeksi virus yang menyerang saluran pernapasan saat ini menjadi masalah utama secara global. Jumlah kasus akibat virus dari hari ke hari semakin meningkat. Berbagai upaya telah diupayakan pemerintah seperti penerapan protokol kesehatan pada masyarakat. Salah satu penerapan protokol kesehatan adalah penggunaan masker. Studi di Cina telah menemukan bahwa memakai masker wajah dapat berdampak positif pada hasil kesehatan jangka pendek meskipun belum jelas paparan apa yang terkait dengan dampak ini (Cherrie et al., 2018).

Penyebaran dan penularan agen infeksi virus dapat menjadi salah satu risiko yang dihadapi penumpang yang menggunakan moda transportasi Bus. Perbaikan terus menerus diupayakan Pemerintah seperti yang saat ini dikembangkan dalam bidang transportasi adalah pengaplikasian biosmart and safety bus. Hal itu tentunya harus dirancang dengan stake holder yang tepat dengan mempertimbangkan penggunaan ruang tertutup, penggunaan air conditioner (AC), letak tempat duduk, penggunaan masker dan jumlah penumpang di dalam bus (Kumparan, 2020)

. Patogen virus dapat beredar melalui media udara. Partikel dibawa oleh udara dan dapat tinggal selama beberapa jam dalam ruangan. Virus kemungkinan memiliki stabilitas yang lebih tinggi di udara dalam ruangan dengan kepadatan orang yang lebih besar (Morawska \& Junji, 2020).

Sistem imun adalah semua mekanisme yang digunakan tubuh untuk mempertahankan keutuhannya terhadap bahaya yang dapat ditimbulkan oleh berbagai macam bahan dalam lingkungan hidup. Mekanisme pertahanan mukosa sangat penting dalam mencegah kolonisasi saluran pernapasan oleh patogen dan penetrasi antigen melalui penghalang epitel. Peran IgA dalam pertahanan permukaan mukosa kini telah berkembang dari peran terbatas perekrutan bahan eksogen, menjadi fungsi pelindung yang lebih luas dengan aplikasi potensial dalam imunoterapi. Fungsi tambahan IgA ini diawali dengan pembentukan kompleks imun, yang memicu Fc alpha Receptor I (FcaRI) bersinergi dengan berbagai reseptor lain untuk memperkuat respons inflamasi (Pilette et al., 2001).

IgA adalah imunoglobulin utama yang bertanggung jawab untuk melindungi permukaan epitel mukosa, seperti pada saluran pernapasan yang merupakan jaringan target untuk virus yang menyerang saluran napas (Habibi et al., 2015). Oleh karena itu, IgA merupakan antibodi yang sangat penting sebagai respon imun spesifik dan terlokalisir terhadap virus. IgA mampu secara aktif berkontribusi pada inisisasi inflamasi. Penelitian oleh Olas et al. (2005) menunjukkan bahwa serum IgA menekan produksi sitokin pro-inflamasi seperti TNF dan IL-6 dari monosit yang distimulasi LPS.

Respon inflamasi melibatkan kelompok mediator kompleks seperti interleukin-6 (IL6) bertindak sebagai mediator pro-inflamasi utama untuk induksi respon fase akut. Peningkatan IL6 dapat menjadi faktor penentu individu yang memiliki alergi terhadap udara, debu ataupun mikroba yang masuk dalam sistem pernapasan (Voiriot et al., 2017). Peranan lain IL6 adalah dalam pengembangan antibodi IgA. Semakin rendah kadar IL6 maka kadar IgA akan meningkat. Semakin tinggi level IL6 maka tinggi pula tingkatan alerginya. Namun sebuah penelitian menyatakan bahwa IL6 memiliki sistem on-off yang berfungsi spesifik dalam mengendalikan peradangan (Ariani, 2019). 
Penggunaan maker kini menjadi kebutuhan dan kewajiban bagi semua orang. Fungsinya adalah melindungi partikel dari aliran udara yang dihirup dengan filtrasi. Efisiensi filtrasi bergantung pada ukuran partikel, muatan, konsentrasi, dan laju aliran melalui bahan filter. Saat ini penggunaan masker belum sepenuhnya maksimal, oleh karena itu perlu diperkaya dengan bahan alami lain guna memaksimalkan kemampuan proteksi dan digunakan sebagai perbaikan sistem pernapasan (Cherrie et al., 2018).

Bunga Hibiscus rosa-sinensis yang mengandung senyawa flavonoid, tannin dan triterpenoid dan daun Nephrolepis exaltata yang mengandung minyak esensial sebagai antioksidan dan antiinflamasi serta flavonoid mempunyai kemampuan proteksi terhadap perbaikan atau efek patologi, mengurangi risiko peradangan jalan napas atas dan memperbaiki sistem paru (Tulangow et al., 2016). Ekstrak kedua tanaman tersebut digunakan sebagai pelapis bahan pembuatan masker guna memaksimalkan fungsi proteksi masker terhadap polutan dan patogen. Penggunaan masker herbal kombinasi dalam moda transportasi biosmart and safety bus diharapkan dapat mengurangi dampak dari persebaran virus dengan sistem dan protokol yang tepat. Hasil setelah penggunaan masker herbal diharapkan dapat menaikkan jumlah IgA dan menurunkan IL6 pada penumpang biosmart and safety bus (Prasetyo et al., 2019).

\section{METODE}

Penelitian ini merupakan quasi experimental dengan pretest dan posttest randomized control trial. Populasi target pada penelitian ini adalah penumpang biosmart and safety bus yang telah dipilih berdasarkan kuesioner penjaringan. Pemilihan sampel dilakukan dengan metode purposive random sampling. Sampel diambil dari populasi yang memenuhi kriteria inklusi (berbadan sehat, usia 15-64 tahun, bukan perokok berat) dan tidak masuk kriteria ekslusi (memiliki riwayat penyakit saluran pernapasan, kelainan herediter, dan dalam kondisi hamil). Sampel yang diambil adalah cuci hidung sebelum dan sesudah menggunakan masker sesuai kelompok. Dilakukan blind test untuk meminimalisir bias. Setelah pengumpulan sampel, dilakukan analisis laboratorium dengan metode ELISA untuk menguji kadar IgA dan IL6.

Analisis statistika dengan menggunakan uji normalitas data menggunakan uji Shapiro-Wilk. Apabila data terdistribusi normal dilakukan uji parametrik paired t-test dan jika tidak terdistribusi normal maka data diolah dengan uji non parametrik Wilcoxon. Perbedaan dianggap bermakna jika nilai $p<0,05$ dengan taraf kepercayaan 95\%. Perubahan nilai IgA dan IL-6 yang pada kelompok kontrol dan kelompok perlakuan dibandingkan dengan melihat nilai $\mathrm{p}$ yang dihasilkan dari uji komparatif numerik tidak berpasangan kedua kelompok tersebut. Independent t-test digunakan apabila disribusi data normal dan uji Mann-Whitney digunakan apabila distribusi data tidak normal.

\section{Demografi Subyek Penelitian}

Total subyek penelitian yang mengikuti penelitian ini adalah sebanyak 31 orang dan dilaksanakan selama 2 hari. Penelitian terdiri dari kelompok kontrol sebanyak 16 orang dan kelompok perlakuan yang masing-masing diberikan masker medis dan masker herbal. 


\section{Masker Herbal Kombinasi}

Lapisan pada masker medis terdiri dari spoundbound-melt bound 3 layer, sedangkan lapisan masker herbal terdiri dari spoundbound-melt bound 3 layer dan dilapisi ekstrak Hibiscus rosa-sinensis dan Nephrolephis exaltata. Spray ekstrak herbal diberikan pada lapisan kedua masker.

\section{Pemeriksaan Kesehatan}

Dilakukan rapid tes antibodi sebagai salah satu syarat mengikuti penelitian. Subyek yang telah menandatangani informed consent kemudian dilakukan pengukuran berat badan, tinggi badan, tekanan darah, dan suhu tubuh.

\section{Pengambilan Sampel Cuci Hidung}

Sampel cuci hidung diambil sebanyak 2 kali sebelum mengenakan masker dan setelah mengenakan masker. Pengambilan sampel cuci hidung dilakukan dengan metode Naclerio et al. (1983) sampel diambil sebanyak $20 \mathrm{ml}$ setiap responden, dimasukkan kedalam tube dan diberi label. Setelah pengambilan sampel pre test dilakukan pengundian untuk menentukan kelompok masker (masker medis dan masker herbal).

\section{Perjalanan Menggunakan Bus}

Perjalanana dilakukan di malam hari untuk meminimalisir aktivitas responden. Seluruh responden penelitian diwajibkan mengenakan masker selama perjalanan sesuai dengan kelompok masker yang telah diundi secara acak. Perjalanan dilakukan selama 6 jam (Adar et al., 2007). Diberikan waktu istirahat untuk makan selama 30 menit dan tidak diperkenakan melakukan aktivitas yang dapat menimbulkan bias seperti merokok. Setelah melakukan perjalanan dilakukan kembali pengambilan sampel cuci hidung untuk mengukur kada IgA dan IL6 setelah perlakuan.

\section{HASIL DAN PEMBAHASAN}

Penelitian ini merupakan Quasi experimental dengan pretest dan posttest randomized control trial. Fokus penelitian pada kadar Imunoglobulin A (IgA) dan Interleukin 6 (IL6) pada sampel cuci hidung penumpang biosmart and safety bus. Total subyek penelitian yang mengikuti penelitian ini adalah sebanyak 31 orang dan dilaksanakan selama 2 hari. Penelitian terdiri dari kelompok kontrol sebanyak 16 orang dan kelompok perlakuan yang masing-masing diberikan masker medis dan masker herbal. Data demografi responden dapat dilihat pada Tabel 1.

Tabel 1. Data Demografi Responden

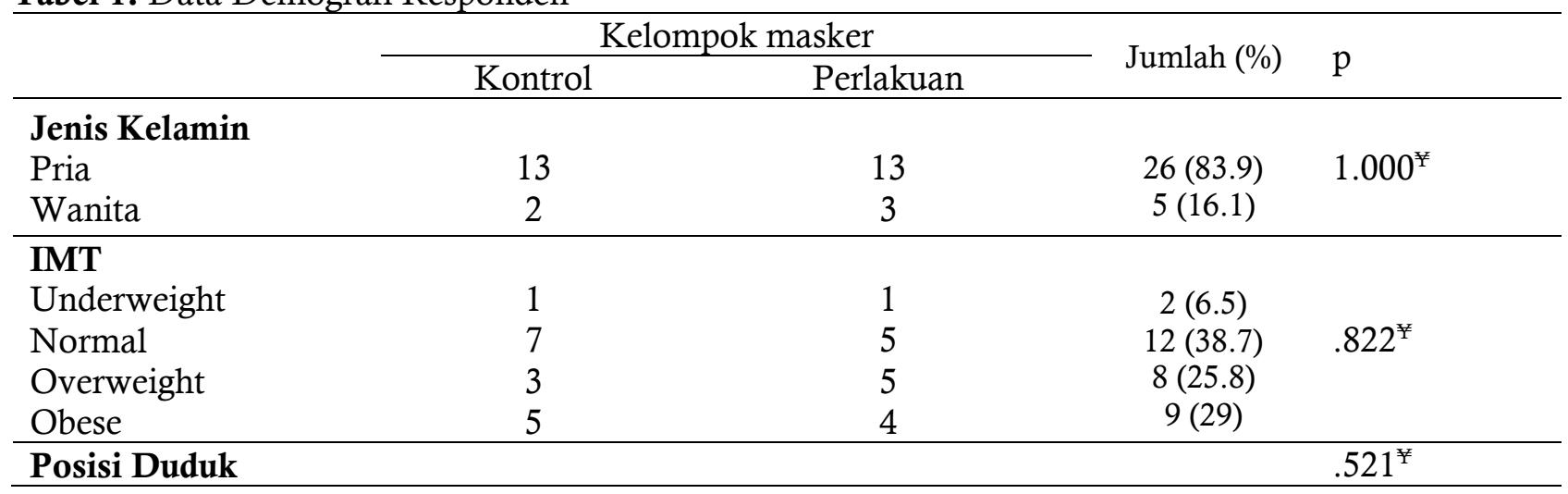




\begin{tabular}{llcc}
\hline Depan & 5 & 7 & $12(38.7)$ \\
Tengah & 6 & 3 & $9(29)$ \\
Belakang & 5 & 5 & $10(32.3)$ \\
\hline Jenis masker & 16 & 15 & $31(100)$ \\
\hline
\end{tabular}

Keterangan: $¥$ Chi Square test

Hasil analisis deskriptif berdasarkan pada hasil pengambilan konsentrasi IgA pada subjek di kelas kontrol sebelum dan setelah melakukan perjalanan dengan Biosmart dan Safety Bus mengenakan masker medis adalah sebagai berikut.

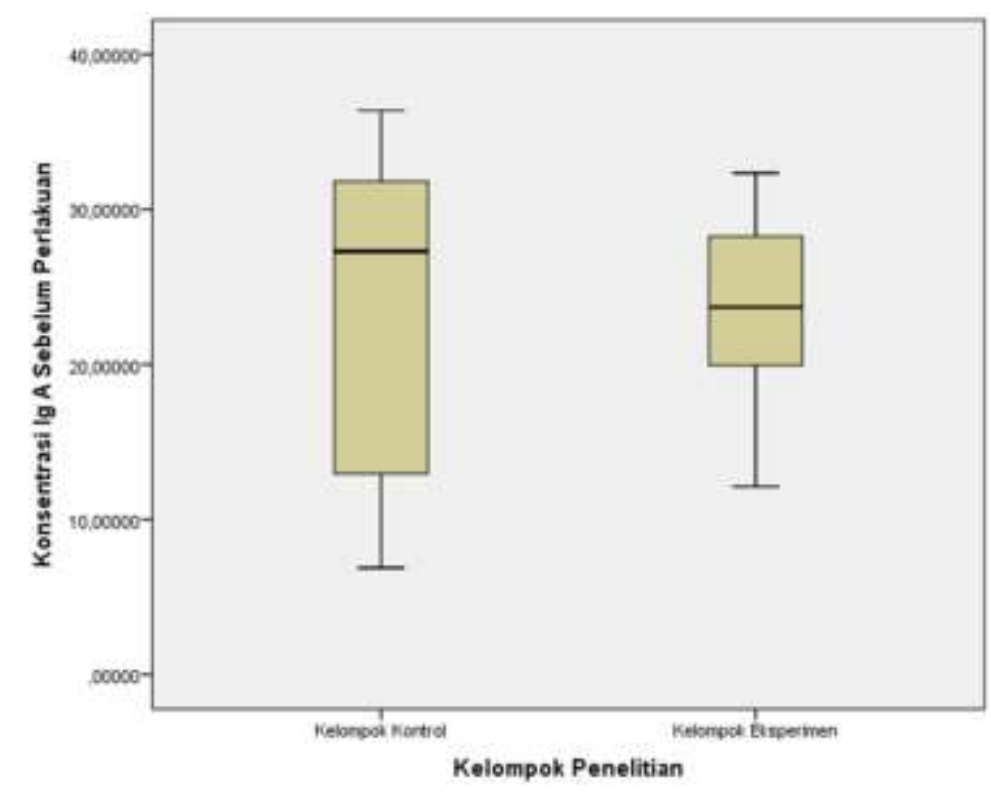

Konsentrasi IgA terendah di kelas kontrol pada saat pengambilan data awal sebelum melakukan perjalanan sebesar 6,87702 pg/ml, konsentrasi tertinggi sebesar 36,37300 pg/ml, rerata konsentrasi IgA sebesar 23,46834 pg/ml, dan standar deviasi sebesar 10,03739. Konsentrasi Ig A terendah di kelas eksperimen pada saat pengambilan data awal sebelum melakukan perjalanan sebesar 12,11590 pg/ml, konsentrasi tertinggi sebesar 32,33390 pg/ml, rerata konsentrasi IgA sebesar 24,00840 pg/ml, dan standar deviasi sebesar 5,54168. 


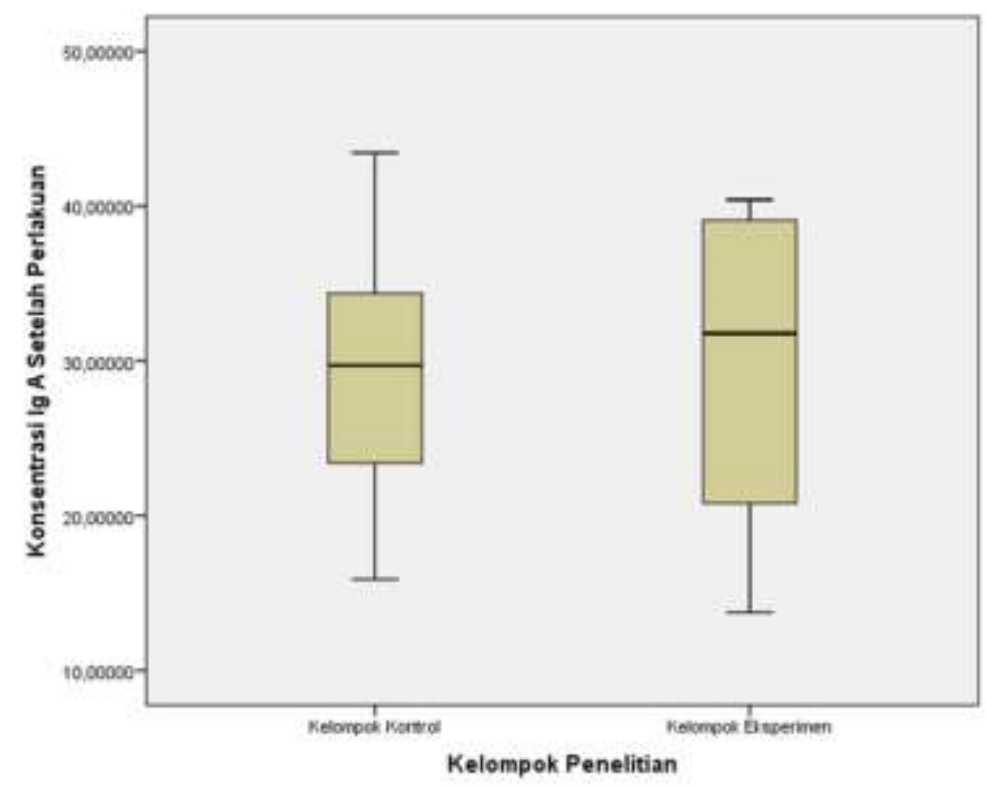

Setelah melakukan perjalanan mengenakan masker medis, hasil konsentrasi IgA terendah sebesar $15,90850 \mathrm{pg} / \mathrm{ml}$, konsentrasi tertinggi sebesar 43,44450 pg/ml, rerata konsentrasi IgA sebesar 29,74473 $\mathrm{pg} / \mathrm{ml}$, dan standar deviasi sebesar 7,66296. Setelah melakukan perjalanan mengenakan masker herbal kombinasi, hasil konsentrasi Ig A terendah sebesar 13,76990 pg/ml, konsentrasi tertinggi sebesar 40,41260 $\mathrm{pg} / \mathrm{ml}$, rerata konsentrasi IgA sebesar 29,74473 pg/ml, dan standar deviasi sebesar 9,70235.

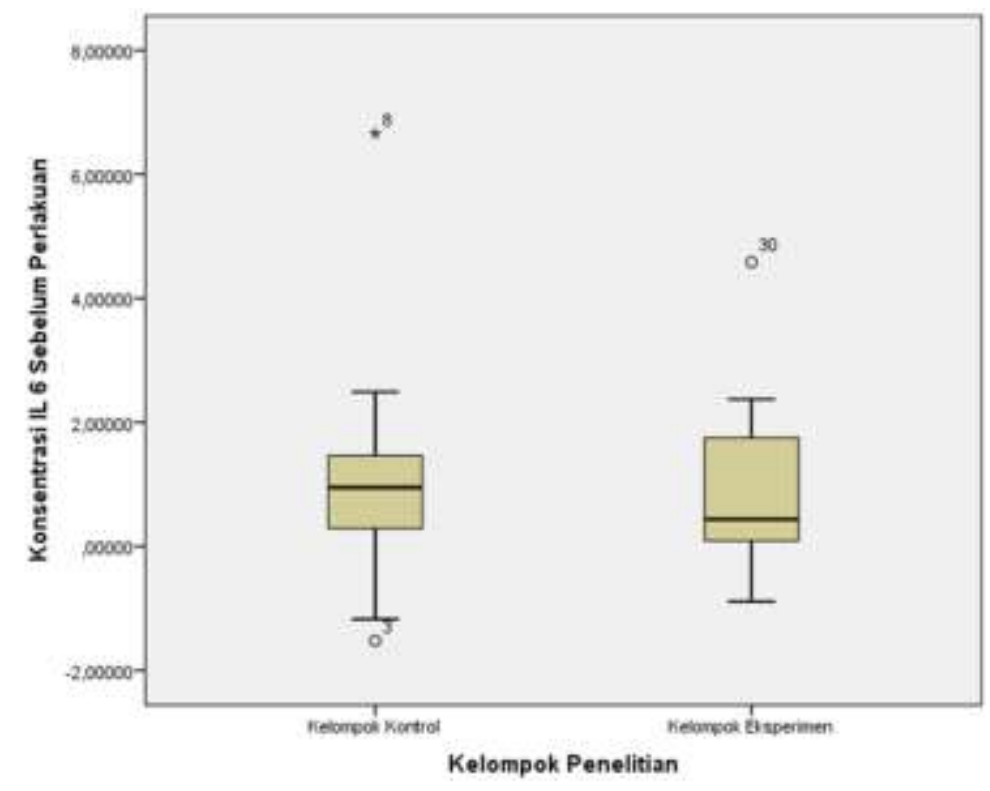

Konsentrasi IL-6 terendah di kelas kontrol pada saat pengambilan data awal sebelum melakukan perjalanan sebesar -1,52060 ng/ml, konsentrasi tertinggi sebesar 6,65899 ng/ml, rerata konsentrasi IL-6 sebesar 1,10544 ng/ml, dan standar deviasi sebesar 1,80416. Adapun konsentrasi IL-6 terendah di kelas eksperimen pada saat pengambilan data awal sebelum melakukan perjalanan sebesar $-0,88586 \mathrm{ng} / \mathrm{ml}$, konsentrasi tertinggi sebesar 4,58350 ng/ml, rerata konsentrasi IL-6 sebesar 0,91682 ng/ml, dan standar deviasi sebesar 1,39592. 


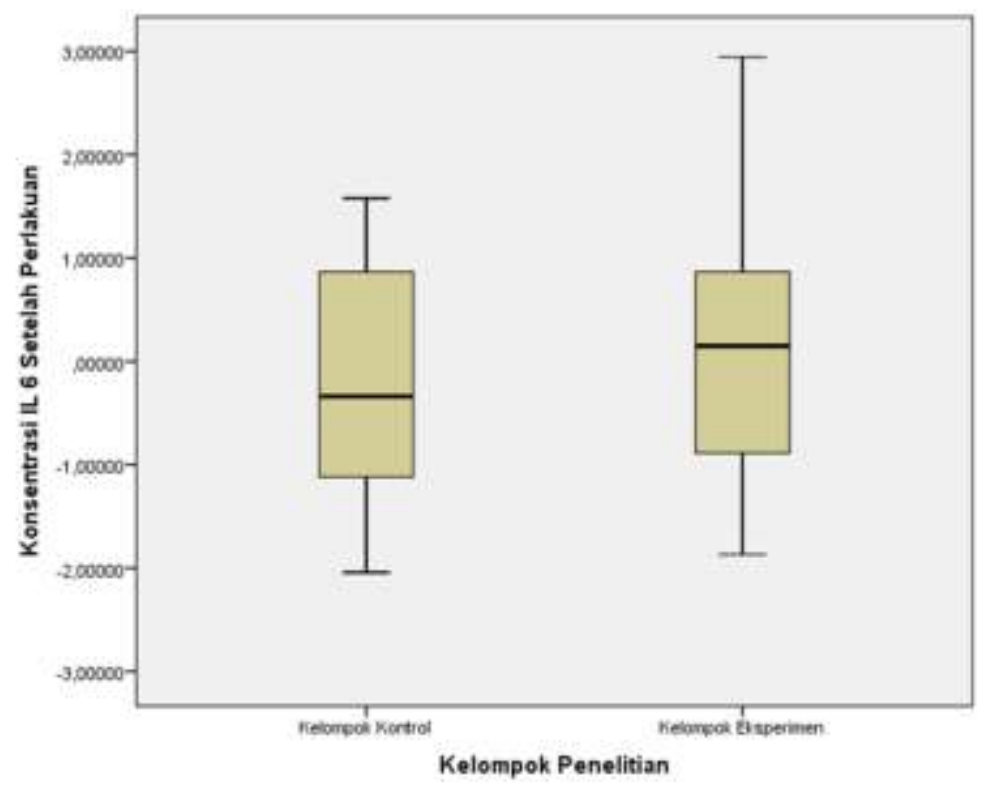

Setelah melakukan perjalanan mengenakan masker medis, hasil konsentrasi IL-6 terendah sebesar $-2,04119 \mathrm{ng} / \mathrm{ml}$, konsentrasi tertinggi sebesar $-1,57932 \mathrm{ng} / \mathrm{ml}$, rerata konsentrasi IL-6 sebesar 0,20200 $\mathrm{ng} / \mathrm{ml}$, dan standar deviasi sebesar 1,25082. Setelah melakukan perjalanan mengenakan masker herbal kombinasi, hasil konsentrasi IL-6 terendah sebesar -1,86754 ng/ml, konsentrasi tertinggi sebesar 2,94432 ng/ml, rerata konsentrasi IL-6 sebesar 0,500157 ng/ml, dan standar deviasi sebesar 1,33981.

Sebelum dilakukan pengujian menggunakan uji sampel berpasangan (paired t-test) diperlukan uji normalitas untuk mengetahui apakah sebaran data yang digunakan dalam penelitian berasal dari populasi berdistribusi normal. Adapun hasil uji normalitas dengan Shapiro Wilk sebagai berikut.

\begin{tabular}{|c|c|c|c|c|c|c|c|}
\hline \multirow{2}{*}{$\begin{array}{l}\text { Variabel } \\
\text { penelitian }\end{array}$} & \multirow{2}{*}{$\begin{array}{l}\text { Kelompok } \\
\text { Penelitian } \\
\end{array}$} & \multicolumn{3}{|c|}{ Kolmogorov-Smirnov $^{\mathrm{a}}$} & \multicolumn{3}{|c|}{ Shapiro-Wilk } \\
\hline & & Statistic & $\mathrm{df}$ & Sig. & Statistic & $\mathrm{df}$ & Sig. \\
\hline \multirow{2}{*}{$\begin{array}{l}\text { Konsentrasi IL } 6 \\
\text { Sebelum Perlakuan }\end{array}$} & Kelompok Kontrol & ,233 & 16 &, 020 & ,818 & 16 &, 005 \\
\hline & $\begin{array}{l}\text { Kelompok } \\
\text { Eksperimen }\end{array}$ & ,206 & 15 & ,087 & 890 & 15 & ,067 \\
\hline \multirow{2}{*}{$\begin{array}{l}\text { Konsentrasi IL } 6 \\
\text { Setelah Perlakuan }\end{array}$} & Kelompok Kontrol &, 115 & 16 & ,200* & ,933 & 16 & ,274 \\
\hline & $\begin{array}{l}\text { Kelompok } \\
\text { Eksperimen }\end{array}$ & ,108 & 15 & ,200* & 959, & 15 & ,675 \\
\hline \multirow{2}{*}{$\begin{array}{l}\text { Konsentrasi Ig A } \\
\text { Sebelum Perlakuan }\end{array}$} & Kelompok Kontrol & ,218 & 16 &, 040 & ,879 & 16 & ,038 \\
\hline & $\begin{array}{l}\text { Kelompok } \\
\text { Eksperimen }\end{array}$ & ,134 & 15 & ,200* & ,957 & 15 & 648 \\
\hline \multirow[b]{2}{*}{$\begin{array}{l}\text { Konsentrasi Ig A } \\
\text { Setelah Perlakuan }\end{array}$} & Kelompok Kontrol & , 131 & 16 & ,200* & ,976 & 16 & ,924 \\
\hline & $\begin{array}{l}\text { Kelompok } \\
\text { Eksperimen }\end{array}$ & ,228 & 15 & ,034 & ,866 & 15 & ,030 \\
\hline
\end{tabular}

Berdasarkan pada hasil uji normalitas dengan Shapiro-Wilk, nilai Sig. untuk data konsentrasi IgA pada kelompok kontrol sebesar 0,038 sehingga dapat disimpulkan bahwa data konsentrasi IgA pada kelompok kontrol sebelum diberikan perlakuan tidak berasal dari populasi berdistribusi normal, sedangkan nilai Sig. untuk data konsentrasi IgA pada kelompok eksperimen sebelum diberikan perlakuan 
sebesar 0,648 sehingga dapat ditarik simpulan bahwa data konsentrasi Ig A pada kelompok eksperimen sebelum diberikan perlakuan berasal dari populasi berdistribusi normal

Nilai Sig. untuk data konsentrasi IgA pada kelompok kontrol setelah diberikan perlakuan sebesar 0,924, sehingga dapat disimpulkan bahwa data konsentrasi IgA pada kelompok kontrol berasal dari populasi berdistribusi normal, sedangkan untuk kelompok eksperimen sebesar 0,030 sehingga dapat disimpulkan bahwa data konsentrasi IgA pada kelompok eksperimen setelah diberikan perlakuan tidak berasal dari populasi berdistribusi normal.

Nilai Sig. untuk data konsentrasi IL-6 pada kelompok kontrol sebelum diberikan perlakuan sebesar 0,005 sehingga dapat ditarik simpulan bahwa data konsentrasi IL-6 pada kelompok kontrol sebelum diberikan perlakuan tidak berasal dari populasi berdistribusi normal, sedangkan untuk kelompok eksperimen sebesar 0,067 sehingga dapat disimpulkan bahwa data konsentrasi IL-6 pada kelompok eksperimen sebelum diberikan perlakuan berasal dari populasi berdistribusi normal.

Nilai Sig. untuk data konsentrasi IL-6 pada kelompok kontrol dan eksperimen setelah diberikan perlakuan sebesar 0,274 dan 0,675 sehingga dapat ditarik simpulan bahwa data konsentrasi IL-6 pada kelompok kontrol dan eksperimen setelah diberikan perlakuan berasal dari populasi berdistribusi normal.

\section{Tabel Uji Wilcoxon}

\begin{tabular}{ll}
\hline Variabel Penelitian & Asym Sig. (2-tailed) \\
\hline IgA Kontrol & .049 \\
\hline IgA Eksperimen & .061 \\
\hline IL6 Kontrol & .007 \\
\hline IL6 Eksperimen & .061
\end{tabular}

Keterangan : Kontrol (masker medis), Eksperimen (Masker herbal)

Hasil uji Wilcoxon menunjukkan bahwa Asymp. Sig. (2-tailed) sebesar 0,049. Dikarenakan nilai Sig. $<0,05$ maka dapat disimpulkan bahwa terdapat perbedaan antara konsentrasi Ig A pada kelompok kontrol sebelum dan setelah mengenakan masker medis selama perjalanan. Hasil uji Wilcoxon menunjukkan bahwa Asymp. Sig. (2-tailed) sebesar 0,061. Dikarenakan nilai Sig. $>$ 0,05 maka dapat disimpulkan bahwa tidak terdapat perbedaan antara konsentrasi Ig A pada kelompok eksperimen sebelum dan setelah mengenakan masker herbal kombinasi selama perjalanan.

Hasil uji Wilcoxon menunjukkan bahwa Asymp. Sig. (2-tailed) sebesar 0,007. Dikarenakan nilai Sig. $<0,05$ maka dapat disimpulkan bahwa terdapat perbedaan antara konsentrasi IL 6 pada kelompok kontrol sebelum dan setelah mengenakan masker medis selama perjalanan. Hasil uji Wilcoxon menunjukkan bahwa Asymp. Sig. (2-tailed) sebesar 0,061. Dikarenakan nilai Sig. > 0,05 maka dapat disimpulkan bahwa tidak terdapat perbedaan antara konsentrasi IL 6 pada kelompok eksperimen sebelum dan setelah mengenakan masker herbal kombinasi selama perjalanan.

Masker yang efektif pada prinsipnya bergantung pada jenis dan tingkat kerapatannya.81 Masyarakat menggunakan masker tidak hanya pada batas efektivitasnya melainkan digunakan terus menerus sebelum masker tersebut rusak. Hal tersebut tentu mengurangi efektivitas daya proteksi masker. 
Pada penelitian ini masker digunakan selama lebih dari 10 jam dimana telah melampaui batas efektivitasnya yaitu 6-8 jam. Sebuah studi di Cina menyebutkan bahwa penggunaan masker lebih dari 6 jam dapat meningkatkan potensi penularan virus yang dibuktikan pada $10 \%$ dari 148 responden (Chughtai, 2019).

Penggunaan masker lebih dari 10 jam tersebut dikarenakan jarak perjalanan yang ditempuh dan kendala yang terjadi selama perjalanan seperti macet. Sehingga daya proteksi masker menurun dan kurang efektif dalam fungsinya. Monitoring dilakukan selama perjalanan, sebanyak 31 responden tidak ada yang mengeluh karena pemakaian masker. Respon dari penumpang yang menjadi subyek penelitian baik, terlebih yang memakai masker herbal. Masker dirasa wangi dan dapat memproteksi bau tidak sedap di sekitar ketika berada di luar bus.

Pada penelitian sebelumnya penggunaan ekstrak herbal Nephrolephis exaltata masih memiliki kekurangan yaitu bau amis yang tercium saat pemakaian masker (Prasetyo et al., 2019). Saat ini dilakukan penambahan ekstrak Hibiscus rosa-sinensis untuk meminimalisir bau amis dan tentunya menambah daya proteksi dari masker herbal. Terbukti pada pemakaian oleh penumpang Biosmart and Safety bus tidak ada yang mengeluhkan bau. Nephrolepis exaltata memiliki kemampuan filtrasi yang baik untuk menyerap polutan udara. Sementara kandungan flavonoid yang terdapat dalam Hibiscus rosa-sinensis dapat menstimulasi respon imun humoral dengan adanya peningkatan titer antibodi sebesar $38.15 \%$ (Nidhi \& Vijay, 2012). Selain itu kandungan antioksidan juga dapat menangkal radikal bebas, dimana fungsinya dapat meningkatkan daya proteksi masker herbal.

Aktivitas antioksidan dari tanaman herbal berkaitan dengan kandungan fenolik dan flavonoidnya. Fraksi etil asetat dari kandungan fenol dan flavonoid berjumlah tinggi sehingga berpotensi sebagai antioksidan dan penghambat karsinogenesis yang baik, sementara flavonoid bertindak sebagai penyerap berbagai spesies pengoksidasi seperti superoksida anion, radikal hidroksil atau radikal peroksi (Verma, 2017)

Secara khusus IgA pada permukaan mukosa telah terbukti berperan dalam mengurangi pelepasan virus (Gould et al., 2017). Volume sampel sangat berpengaruh pada kadar immunoglobulin yang diujikan. Volume kecil MLF hidung atau cairan mukosa pada hidung yang dapat diperoleh, pengujian sensitif diperlukan untuk mengukur imunitas humoral dalam sampel ini. Salah satu kelemahan potensial ELISA adalah volume sampel yang tinggi yang diperlukan, terutama jika kadar antibodi yang rendah memerlukan bahan yang tidak diencerkan dan IgA khusus untuk beberapa antigen diukur (Thushan et al., 2017).

Interleukin-6 dilepaskan sebagai respons terhadap infeksi dan merangsang jalur inflamasi sebagai bagian dari respon fase akut. Interleukin- 6 adalah sitokin multifungsi yang telah terbukti meningkat dalam beberapa kondisi patologis yang melibatkan sistem pernapasan seperti yang diinduksi secara eksperimental pada hewan atau secara spontan terjadi pada manusia. Interleukin-6 memiliki peran kausatif dalam menentukan peningkatan resistensi saluran napas (Rubini, 2013)

Data penelitian menunjukkan bahwa kedua kelompok sebagian besar mengalami penurunan IL6. Namun secara statistika kelompok kontrol yang signifikan mengalami penurunan. Total rerata penurunan 
pada kelompok kontrol adalah $120,00 \mathrm{ng} / \mathrm{ml}$ dengan $\mathrm{p}$ value 0,049 . Sementara total rerata penurunan kelompok eksperimen adalah 93,00 $\mathrm{ng} / \mathrm{ml}$ dengan $\mathrm{p}$ value 0.061 dapat dikatakan hampir signifikan.

Meskipun mengalami penurunan secara matematika namun jika dianalisa secara statistika hasilnya mendekati signifikan dan kurang sesuai dengan hipotesis. Beberapa penelitian mengatakan keberadaan sitokin tersebut belum jelas. IL6 merupakan sitokin yang bertugas sebagai pemicu fase akut atau memiliki aktivitas proinflamasi dan anti-inflamasi pada kondisi tertentu. Jika demikian dapat dikatakan IL6 memiliki sistem on-off yang berfungsi spesifik mengendalikan inflamasi (Ariani, 2019).

Pada kondisi kronis, IL6 tidak berfungsi sebagai penginduksi reaksi fase akut tetapi memainkan peran penting dalam respon imun seluler dan respon imun humoral dalam melawan infeksi berulang. Aktivitas yang dilakukan sitokin tersebut merupakan upaya untuk mengembalikan keadaan homeostasis dan dapat dikatakan IL6 memiliki peran ganda dalam regulasi inflamasi (Ariani, 2019).

IL6 memiliki 2 jalur pensinyalan yaitu IL6 klasik dan trans sinyal. Untuk menentukan apakah suatu penyakit yang berkaitan dengan respon IL6 dapat dilakukan secara in vivo dan in vitro. Pada penelitian dengan menggunakan protein sgp $130 \mathrm{Fc}$ terbukti menjadi alat molekuler untuk membedakan antara IL-6 klasik dan trans-signaling in vitro dan in vivo. Konsentrasi IL6 orang sehat dalam darah berada dalam kisaran 1 pg / ml. 86 Sebaliknya, konsentrasi sIL-6R dan sgp130 masing-masing berada dalam kisaran 50-75 $\mathrm{ng} / \mathrm{ml}$ dan $400 \mathrm{ng} / \mathrm{ml}$. Dalam perjalanan keadaan inflamasi, kadar sgp130 sebagian besar dipertahankan sedangkan konsentrasi sIL-6R biasanya meningkat dengan faktor tertentu. Selama peradangan atau infeksi, IL6 disekresikan oleh neutrofil, monosit, makrofag, fibroblas, sel endotel, sel otot polos dan sel-T (Wahyu, 2012)

Pensinyalan yang diinduksi oleh IL6 dapat dihambat baik dengan menargetkan bagian ekstraseluler atau bagian intraseluler dari pensinyalan IL6. Menargetkan protein larut ekstraseluler (misalnya IL6 atau sIL-6R) atau domain ekstraseluler protein transmembran (misalnya IL-6R) lebih spesifik dan lebih mudah daripada menargetkan struktur intraseluler, seperti kinase, karena aksesibilitasnya yang terbatas. Struktur ekstraseluler dapat ditargetkan dengan biologis, seperti antibodi monoklonal (misalnya Tocilicumab, yang mengikat IL-6R) atau reseptor terlarut (mislnya sgp130fc, yang menetralkan kompleks IL-6: sIL-6R). Sebaliknya, penargetan intraseluler dapat dicapai dengan inhibitor farmasi molekul rendah yang berdifusi melintasi membran sel (misalnya, inhibitor JAK Janus kinase) atau dengan memanfaatkan crosstalk antara sitokin dan pensinyalan hormon (Schaper \& Rose 2015).

Beberapa faktor yang dapat mempengaruhi kadar IgA dan IL6 pada studi ini adalah sebagai berikut:

1. Lama waktu penggunaan masker

Seperti yang telah disebutkan, bahwa pengunaan masker pada penelitian ini melebihi durasi waktu efektif yang ada. Hal tersebut tentunya menjadi salah satu faktor yang mempengaruhi kadar immunoglobulin dan reaksi inflamasi pada sampel yang diujikan. Terlebih perjalanan yang cukup jauh membuat penurunan kondisi fisik yang tentunya dapat mempengaruhi hal tersebut.

2. Merokok 
Secara teori, aktivitas merokok dapat mempengaruhi produksi sitokin pro inflamasi akibat paparan zat berbahaya yang terinhalasi. Hal tersebut tentunya menimbulkan bias pada penelitian yang dilakukan. Responden yang turut serata dalam penelitian ini telah diinstruksikan untuk tidak merokok. Namun pada faktanya masih ada beberapa responden yang menghiraukan instruksi tersebut.

Aktivitas merokok dapat menurunkan kadar IgA saliva secara progresif dimana IgA merupakan garis pertahanan pertama dari host terhadap patogen. Merokok telah terbukti mempengaruhi penurunan aktivitas sel pembunuh alami, konsentrasi serum immunoglobulin, merusak imunoregulasi sel-T dari diferensiasi dan pematangan sel-B sehingga menyebabkan penurunan tingkat SIgA. Kadar imunoglobulin yang rendah merupakan faktor predisposisi penting dalam perkembangan infeksi yang terkait dengan merokok. Hasil penelitian yang dilakukan oleh Jamil et al. (2017) menunjukkan bahwa peningkatan IL6 terjadi pada perokok aktif. IL6 telah dianggap sebagai penanda umum terjadinya inflamasi bersamaan dengan TNF $\alpha$ dan IL1 $\beta$.

3. Usia, Gender dan IMT

Usia dapat mempengaruhi Indeks Massa Tubuh (IMT) karena semakin bertambahnya usia manusia cenderung jarang melakukan olahraga dan membatasi aktivitas. Ketika demikian, maka berat badannya cenderung meningkat sehingga mempengaruhi Indeks Massa Tubuh (IMT). Dari data penelitian, terlihat bahwa perbandingan pria dan wanita tidak seimbang, sementara IMT yang masuk kategori over dan obese terjadi pada pria dalam usia dewasa muda. Oleh sebab itu belum jelas apakah ada perbedaan IMT dengan penggunaan masker jika dibandingkan dengan gender penumpang.

4. Penyimpanan Sampel

Sampel pengujian baik pre test maupun post test telah diupayakan disimpan dalam kondisi yang semestinya. Namun dikarenakan perjalanan transfer sampel yang jauh dan cukup memakan waktu, kemungkinan terjadinya perbedaan hasil sangat mempengaruhi.

Penelitian ini memiliki beberapa keterbatasan yang perlu ditekankan. Beberapa bias sulit dikendalikan seperti durasi penggunaan masker, durasi perjalanan, aktivitas merokok serta informasi pengobatan pribadi yang mempengaruhi konsentrasi variabel yang diujikan.

\section{SIMPULAN}

Masker Herbal dan masker medis sama-sama memiliki kemampuan dalam memproteksi saluran napas penumpang Biosmart and Safety Bus yang dibuktikan dengan peningkatan kadar IgA dan penurunan kadar IL6. Daya proteksi lebih baik menggunakan masker herbal namun secara statistik hampir mendekati signifikan. 


\section{UCAPAN TERIMA KASIH}

Kami ucapkan terima kasih kepada Universitas Diponegoro atas dukungan dana penelitian hibah tahun 2021. Terima kasih kepada PT Laksana Karoseri Ungaran, PO Sumber Alam dan KNKT atas dukungan dalam penelitian ini.

\section{DAFTAR PUSTAKA}

Adar, S. D., Gary, A., Diane, R. G., Joel, S., Brent, A. C., \& Helen, S. (2007). Ambient and Microenvironmental Particles and Exhaled Nitric Oxide Before and After a Group Bus Trip. Environ Health Perspect, 115, 507-12. https://doi.org/10.1289/ehp.9386

Ariani, R. 2019. Analisis Efek Proteksi Masker Herbal Nephrolepis exaltata terhadap Kadar Tumor Necrosis Factor- $\alpha$ dan Interleukin 6 Karyawa Industri Tekstil. Tesis, Universitas Diponegoro.

Cherrie, J. W., Andrew, A., Hilary, C., Susanne, S., William, M., Chun, Lin., et al. (2018). Effectiveness of face masks used to protect Beijing residents against particulate air pollution. Occup Environ Med, 75(6), 446-2. https://doi.org/10.1136/oemed-2017-104765

Chughtai, A. A. (2019). Contamination by respiratory viruses on outer surface of medical masks used by hospital healthcare workers. BMC Infectious Diseases. BMC Infectious Diseases, 19(1), 1-8. https://doi.org/10.1186/s12879-019-4109-x.

Gould, V. M. W., Francis, J. N., Anderson, K. J., Georges, B., Cope, A. V., Tregoning, J. S. (2017). Nasal IgA provides protection against human influenza challenge in volunteers with low serum influenza antibody titre Front. Microbiol, 8, 900.

Habibi, M. S., Agnieszka, J., Spyridon, M., Jake, D., Allan, P., John, P. D., et al. (2015). Impaired Antibody-mediated Protection and Defective IgA B-Cell Memory in Experimental Infection of Adults with Respiratory Syncytial Virus. Am J Respir Crit Care Med, 191(9), 1040-9. https://doi.org/10.1164/rccm.201412-2256OC

Jamil, A., Amir, R., Abdul, K. N., \& Maleha, A. (2017). Effect of smoking on interleukin-6 and correlation between IL-6 and serum amyloid a-low density lipoprotein in smokers. $J$ Postgrad Med Ins, 31(4), 336-8.

Kumparan. Bus Jenis Ini Boleh Diisi Penuh Penumpang Selama Masa Pandemi? [Internet]. 2020 [cited 12 Agustus 2020]. Available from: https://kumparan.com/kumparanoto/bus-jenis-ini-bolehdiisi-penuh-penumpang-selama-masa-pandemi-

1trNFfM8RfM/full?shareID=KI6CxtjHkt6O\&utm_campaign=share\&utm_source=kumApp

Morawska, L. \& Junji, C. 2020. Airborne transmission of SARS-CoV-2: The world should face the reality. Env Inter, 139(105730), 1-3.

Naclerio, R. M., Meier, H. L., Sobotka, A. K., Adkinson, N. F., Meyers, D. A., Norman, P. S., et al. (1983). Mediator release after nasal airway challenge with allergen. American Rev of Respi Dis, 128(4), 597-602. https://www.ncbi.nlm.nih.gov/pubmed/6354022.

Nidhi, M. \& Vijay, T. R. G. (2012). Immunomodulation by Hibiscus rosa sinensis L. : effect on humoral and cellular immune response of mus musculus. Pakistan Journal of Biological Science, 15(6), 277 83.

Olas, K., Butterweck, H., Teschner, W., Schwarz, H. P. \& Reipert, B. (2005). Immunomodulatory properties of human serum immunoglobulin A: anti-inflammatory and pro-inflammatory activities in human monocytes and peripheral blood mononuclear cells. Clin Exp Immunol, 140, 478-490.

Pilette, C., Ouadrhiri, Y., Godding, V., Vaerman, J. P. \& Sibille, Y. (2001). Lung mucosal immunity: immunoglobulin-A revisited. Eur Respir J, 18, 571-8.

Prasetyo, A., Rahardja, A. A., Azzahro, D. T., Miranti, I. P., Saraswati, I. \& Kholis, F. N. (2019). Nephrolepis exaltata Herbal Mask Increases Nasal IgA Levels and Pulmonary Function in Textile Factory Workers. Hind Adv Prev Med, 1-7. https://doi.org/10.1155/2019/5687135 
Rubini, A. (2013). Interleukin-6 and Lung Inflammation: Evidence for a Causative Role in Inducing Respiratory System Resistance Increments. Inflammation \& Allergy - Drug Targets (Discontinued), 12, 315. https://doi.org/10.2174/1871528111312050003

Schaper, F. \& Rose-John, S. (2015). Interleukin-6: Biology, signaling and strategies of blockade. Cytokine \& Growth Factor Reviews. 26(5), 475-487. https://doi.org/10.1016/j.cytogfr.2015.07.004.

Thushan, I., Silva, Gould, V., Nuredin, I., Mohammed, Cope, A., et al. (2017). Comparison of mucosal lining fluid sampling methods and influenza-specific IgA detection assays for use in human studies of influenza immunity. Journal of Immunology Methods, 449, 1-6. https://doi.org/10.1016/j.jim.2017.06.008.

Tulangow, L., Edwin, D. Q. \& Herny, S. (2016). Identifikasi Senyawa Fitokimia Dan Uji Toksisitas Dengan Metode Bslt Ekstrak Etanol Bunga Ubu-Ubu (Hibiscus Rosa-Sinensis L.) Dari Maluku Utara. PHAR J Ilmiah Farm, 5(3).

Voiriot, G., Keyvan, R., Valerie, A., Jeanne, T. V., Shariq, A., Serge, A., et al. (2017). Interleukin-6 displays lung antiinflammatory properties and exerts protective hemodynamic effects in a double-hit murine acute lung injury. Respi Research, 18(64), 1-35. https://doi.org/10.1186/s12931-017-0553-6\#Sec1

Verma, S. (2017). Hibiscus rosa-sinensis L. (Malvaceae): A multipurpose ornamental plant. International Journal of Research in Pharmacology and Pharmacotherapeutics, 6(1), 61-4.

Wahyu. (2012). Plastisitas dan cross-talk dari interleukin 6-tipe sitokin. Sitokin Growth Factor [Internet], $23,85-97$. 